\title{
Genetic distance between broodstocks of the marine shrimp Litopenaeus vannamei (Decapoda, Penaeidae) by mtDNA analyses
}

\author{
Ana Karina de Francisco and Pedro Manoel Galetti Junior \\ Universidade Federal de São Carlos, Departamento de Genética e Evolução, São Carlos, SP, Brazil.
}

\begin{abstract}
In the constantly growing Brazilian shrimp industry the evaluation of genetic relationships between broodstocks is an useful tool for shrimp culture management programs. We established the genetic relationships between five broodstocks of the white marine shrimp Litopenaeus vannamei (Penaeidae) based on the sequencing of the mtDNA 16S rRNA and cytochrome oxidase I (COI) regions. Although no divergence was found between the broodstocks for the highly conservative 16S rRNA gene, we did find an $8.2 \%$ distance between $L$. vannamei and the Farfantepenaeus subtilis. Analyses of the COI region showed genetic distances of only 0.2 to $1 \%$ between the broodstocks, which contrasted with the $10.9 \%$ mean distance found between $L$. vannamei and $F$. subtilis. The small genetic distance values obtained may be related to genetic drift or a founder effect that occurred during broodstocks establishment. The mtDNA analysis was able to characterize the genetic divergence between the broodstocks studied and could be helpful for defining better management strategies of these crustacea.
\end{abstract}

Key words: shrimp, Litopenaeus vannamei, genetic variation, mtDNA.

Received: June 25, 2004; Accepted: February 15, 2005.

\section{Introduction}

The white marine shrimp Litopenaeus vannamei is an important aquaculture species reared several American countries, including Brazil. This species is native to the $\mathrm{Pa}-$ cific Ocean with a geographic distribution ranging from the southern coast of Mexico to the southern coast of Peru (Nunes, 2001). Specimens of L. vannamei from different geographical regions were used to compose the Brazilian broodstocks, possibly producing some genetic differentiation among them as resulted from founder effects (Primack, 2002). It is possible that some breeder management practices may be critical to the maintenance of Brazilian captive populations, especially those practices related to the reduction of genetic variability caused by inbreeding and random genetic drift effects (Freitas and Galetti Jr, 2002).

The study of the genetic characteristics of shrimp species and the analysis of genetic relationships between broodstocks can be an useful tool for their management because genetic identification and discrimination of broodstocks are essential to successful rearing programs (Allegrucci et al., 1998; Sekino et al., 2002). Mitochondrial DNA (mtDNA) shows a high level of polymorphism and an evolutionary rate 10 times faster than nuclear genomes and

Send correspondence to Ana Karina de Francisco. Universidade Federal de São Carlos, Departamento de Genética e Evolução, Caixa Postal 676, 13656-905 São Carlos, SP, Brazil. E-mail: pakarina@iris.ufscar.br. is subject to maternal and asexual inheritance (Awadalla et al., 1999), characteristics which make mtDNA very useful for genetic studies in aquaculture (Allegrucci et al., 1998). Sequence analyses of mtDNA have been widely used in phylogenetic studies of natural shrimp populations (Bouchon et al., 1994; Baldwin et al., 1998; Klinbunga et al., 1999; Gusmão et al., 2000; Maggioni et al., 2001) and to evaluate genetic divergence between captive populations (Iguchi et al., 1999; Sekino et al., 2002). The 16S rRNA gene is found in the conserved portion of the mtDNA and has been extensively used in phylogenetic studies while the cytochrome oxidase I (COI) gene, which seems to be less conserved than the 16S rRNA gene, has been frequently used in evolutionary studies (Clary and Wolstenholme, 1985; Beard et al., 1993).

The work described in this paper used mtDNA sequencing of the 16S rRNA and COI genes to analyze the genetic interrelationships between $L$. vannamei broodstocks, detailed knowledge of the genetic features of broodstocks being crucial to the development of captive rearing programs.

\section{Material and Methods}

\section{Sample collection and DNA extraction}

Specimens of the white marine shrimp Litopenaeus vannamei (Penaeidae) were obtained from five broodstocks 
(Aqua-044, Aqua-045, Aqua-046, Aqua-051 and Aquaven) owned by the Aquatec hatchery situated in the northern Brazilian state of Rio Grande do Norte. The Aqua-044 broodstock is an $\mathrm{F}_{3}$ generation and Aqua- 045 an $\mathrm{F}_{4}$ generation, both mainly founded using wild $L$. vannamei imported from Panama but with some specimens from other Brazilian shrimp producers. The Aqua-046 and Aqua-051 broodstocks are both $\mathrm{F}_{1}$ generations, founded mostly using L. vannamei from Secom Farm in the Brazilian state of Ceará but with some specimens from Panama and Ecuador which had been previously reared at the Aquatec hatchery. The Aqua-ven broodstock was founded from an $\mathrm{F}_{17} \mathrm{~L}$. vannamei imported from a Venezuelan.

The 16S rRNA analyses was made using two specimens from each broodstock while the COI gene sequencing used five specimens from each broodstock with the exception of the Aqua- 045 broodstock for which only four specimens were used. Pleopod samples from all specimens were collected and stored in $1 \mathrm{~mL}$ of absolute ethanol at $-20^{\circ} \mathrm{C}$. Genomic DNA was extracted according to the procedure described by Sambrook et al. (1989).

\section{PCR, sequencing and data analyses}

The 16S rRNA region was polymerase chain reaction (PCR) amplified using the primers 16Sar (5'-GCCTGTTT AACAAAAACAT-3') and 16Sbr (5'-CCGGTCTGAACT CAGATCATGT-3') (Simon et al., 1991). Amplification was carried out in a $50 \mu \mathrm{L}$ final volume of $1 \mathrm{x}$ buffer containing $5 \mathrm{mM} \mathrm{MgCl}_{2}, 200 \mathrm{mM}$ dNTPs, 4 units of Taq DNA polymerase, $50 \mathrm{ng}$ of genomic DNA and $50 \mathrm{ng}$ of each primer using $5 \mathrm{~min}$ of initial denaturation at $93{ }^{\circ} \mathrm{C}$, followed by 30 cycles of $30 \mathrm{~s}$ at $93{ }^{\circ} \mathrm{C}, 30 \mathrm{~s}$ at $50{ }^{\circ} \mathrm{C}, 45 \mathrm{~s}$ at $72^{\circ} \mathrm{C}$ and a final extension $5 \mathrm{~min}$ at $72^{\circ} \mathrm{C}$. The $\mathrm{COI}$ region was PCR amplified using the primers CO9 (5'-TTCGGTT CA(T/C)CCAGAAGT(C/A)TAT-3') and CO10 (5'-TAA GCGTCTGGGTAGTCTGA(A/G)TA(T/G)CG-3') (Baldwin et al., 1998). Amplification was carried out in a $25 \mu \mathrm{L}$ final volume of $1 \mathrm{x}$ buffer containing $1.5 \mathrm{mM} \mathrm{MgCl}_{2}$, $200 \mathrm{mM}$ dNTPs, $200 \mathrm{nM}$ of each primer, 3 units of Taq DNA polymerase and $10 \mathrm{ng}$ of genomic DNA using $3 \mathrm{~min}$ of initial denaturation at $94{ }^{\circ} \mathrm{C}$, followed by 35 cycles of 1 min at $94{ }^{\circ} \mathrm{C}, 1 \mathrm{~min}$ at $45^{\circ} \mathrm{C}, 1 \mathrm{~min}$ at $72{ }^{\circ} \mathrm{C}$ and final extension of $5 \mathrm{~min}$ at $72{ }^{\circ} \mathrm{C}$. The amplification products were purified using the Wizard PCR Preps DNA Purification System kit (Promega), and then coupled to the pGEM-T vector (pGEM-T Easy System II kit - Promega) for further transformation in competent DH5 $\alpha$ Escherichia coli cells. The FlexiPrep kit (Amersham Pharmacia Biotech) was adapted to perform minipreparations of plasmids from the recombinant clones bearing the selected fragments.

The sequencing of the selected fragments was performed according to Sanger et al. (1977) in an automatic ABI 377 sequencer (Applied Biosystems Inc.). The sequences obtained from three clones of each sample analyzed were aligned using the Multalin site (Copert, 1988) to find a consensus sequence, confirmed by visual inspection, for each specimen. The consensus sequences generated for each specimen were aligned to obtain a single consensus sequence per broodstock and these sequences used to evaluate the genetic distance by the $p$ distance method contained in the Mega 2.1 program (Kumar et al., 1994). Two wild Farfantepenaeus subtilis specimens were used for comparing the magnitude of interspecific divergence.

\section{Results}

The partial 16S rRNA gene sequences consisted of $529 \mathrm{bp}$ fragments with a mean nucleotide composition of adenine $(\mathrm{A})=32 \%$, cytosine $(\mathrm{C})=14.6 \%$, guanine $(\mathrm{G})=21.5 \%$ and thymine $(\mathrm{T})=32 \%$. There were only two 16S rRNA haplotypes in the six broodstocks, one haplotype being shared by all five $L$. vannamei broodstocks while the other haplotype occurred only in F. subtilis. The consensus sequences of all the specimens studied were deposited in GenBank (access numbers: AY344183 to AY344192 for $L$. vannamei and AY344193 and AY344194 for F. subtilis). The total nucleotide diversity and genetic divergence obtained for the L. vannamei broodstocks were equal to zero, contrasting with the 41 divergent sites and $8.2 \%$ genetic distance found between L. vannamei and F. subtilis.

The nucleotide composition of a 595bp fragment from the COI gene (GenBank access numbers: AY344200 to AY344223 for L. vannamei and AY344195 to AY344199 for $F$. subtilis) was $\mathrm{A}=26.8 \%, \mathrm{C}=17.9 \%$, $\mathrm{G}=16.6 \%$, and $\mathrm{T}=38.8 \%$. The total nucleotide diversity within $L$. vannamei was 0.041 . Eight divergent sites were detected for the L. vannamei broodstocks while 70 were observed between $L$. vannamei and $F$. subtilis. Five haplotypes were discriminated within L. vannamei (one for each broodstock) plus one for $F$. subtilis. The genetic divergence for the L. vannamei broodstocks ranged from 0.002 to 0.01 , contrasting with a mean distance of 0.1094 between L. vannamei and F. subtilis (Table 1).

\section{Discussion}

For both shrimp species there was a bias towards A + $\mathrm{T}$ in the base-pair composition of both the 16S rRNA and COI gene sequences, which is commonly the case in most penaeid species (Baldwin et al., 1998; Maggioni et al., 2001). Although 16S rRNA analysis failed to discriminate genetic differences between the $L$. vannamei broodstocks it was able to distinguish haplotypes and 41 divergent sites between $L$. vannamei and $F$. subtilis. The $16 \mathrm{~S}$ rRNA region is known to be conserved and have a low rate of evolution (Meyer, 1994) which means that it is more accurate in discriminating between species than within species. In shrimp, 16S rRNA sequencing has been found to be able to characterize a morphotype usually identified as $F$. subtilis but which displays a different genetic pattern and could be regarded as a new species (Maggioni et al., 2001). However, 
Table 1 - Genetic distance (lower diagonal) and standard deviation values (upper diagonal) obtained from COI gene sequence analysis.

\begin{tabular}{lccccc}
\hline Broodstocks & Aqua-ven & Aqua-051 & Aqua-046 & Aqua-044 & Aqua-045 \\
\hline Aqua-ven & - & 0.002 & 0.002 & 0.003 & 0.004 \\
Aqua-051 & 0.003 & - & 0.002 & 0.003 & 0.013 \\
Aqua-046 & 0.003 & 0.003 & - & 0.002 & 0.04 \\
Aqua-044 & 0.005 & 0.005 & 0.002 & - & 0.004 \\
Aqua-045 & 0.010 & 0.010 & 0.010 & 0.008 & 0.004 \\
F. subtilis & 0.108 & 0.111 & 0.108 & 0.106 & 0.013 \\
\hline
\end{tabular}

the low evolutionary rate of the $16 \mathrm{~S}$ rRNA gene means that there is little or no differentiation between sequences from specimens belonging to the same species, the homogeneity of the L. vannamei broodstocks seen in our study probably being related to the conserved nature of this gene.

In contrast to the situation with the 16S rRNA gene, the five L. vannamei broodstocks showed genetic differentiation in the COI gene analysis. The genetic divergences detected by COI gene analysis were consistently higher than those revealed by analysis of the $16 \mathrm{~S}$ rRNA region. The COI region sequences exhibited sufficient nucleotide diversity to be able to determine the occurrence of one haplotype per broodstock and another for F. subtilis, with 8 divergent sites being detected among the five broodstocks and 70 between L. vannamei and $F$. subtilis. The substitution rate presented by the COI gene was somewhat higher, allowing the detection of genetic differences between different populations of the same species (Conn, 1998; Lee, 2000; Gusmão et al., 2000). Although the genetic distances for the five $L$. vannamei broodstocks were close to zero $(0.2$ to $1 \%$ ) the values were similar to those published by Gusmão et al. (2000) for some penaeid species investigated using COI gene sequencing. In addition, in our study the mean genetic distance between $L$. vannamei and F. subtilis was $10.94 \%$, which was close to the $8.1 \%$ genetic distance obtained by Gusmão et al. (2000) for Farfantepenaeus paulensis and F. subtilis.

Nevertheless, it is probable that the small genetic distance values between the five broodstocks studied by us were not due to mutations that occurred at the time of their foundation but may instead be related to random genetic drift or a founder effects that occurred during the establishment of the broodstocks. Since the mitochondrial genome is maternally inherited without recombination it is to be expected that variation in this genome is highly susceptible to stochastic events such as genetic drift (Bembo et al., 1995). The broodstocks investigated by us may also have been formed by specimens collected from different localities such as Panama and Ecuador and such a divergence, even if only small, may be reflecting the genetic variation present in the natural populations.

However, it is well established that adult $L$. vannamei mate off-shore where their planktonic larvae are submitted to the random effects of winds and tides (Benzie, 2000) and a large genetically homogeneous and panmictic population is to be expected. Moreover, there is no available information on population substructuring in wild population of $L$. vannamei. In addition, microsatellites analyses have not been able to find isolation by distance in populations of Litopenaeus schmitti from eight different localities on the Brazilian coast (Maggioni et al., 2003). Similar results have been obtained by Gusmão et al. (2000) for Farfantepenaeus brasiliensis populations using allozyme analysis.

It thus appears that the genetic divergence observed by us in the five L. vannamei broodstocks studied is the result of random genetic drift or founder effects. It appears that mtDNA analysis allowed us to identify a certain degree of genetic divergence among the broodstocks studied and that this type of analysis could be an important tool for better defining the use of these broodstocks in genetic improvement programs.

\section{Acknowledgments}

The authors thank Aquatec Hatchery for the $L$. vannamei samples studied, and the Associação Brasileira de Criadores de Camarão (ABCC) and the Brazilian agency Conselho Nacional de Desenvolvimento Científico e Tecnológico $(\mathrm{CNPq})$ for financial support.

\section{References}

Allegrucci G, Cesaroni D, Venanzetti F, Cataudela S and Sbordoni V (1998) Length variation in mtDNA control region in hatchery stocks of European sea bass subjected to acclimatation experiments. Genet Sel Evol 30:275-288.

Awadalla PA, Eyre-Walker J and Maynard S (1999) Linkage disequilibrium and recombination in hominid mitochondrial DNA. Science 286:2524-2525.

Baldwin JD, Bass AL, Bowen, BW and Clark Jr WH (1998) Molecular phylogeny and biogeography of the marine shrimp Penaeus. Mol Phylogenet Evol 10:399-407.

Beard CB, Hamm DM and Collins FH (1993) The mitochondrial genome of the mosquito Anopheles gambiae: DNA sequence, genome organization and comparisons with mitochondrial sequences of other insects. Insect Mol Biol 2:103-124

Bembo DG, Carvalho GR, Snow M, Cingolani N and Pitcher TJ (1995) Stock discrimination among european anchovies, 
Engaulis encrasicolus, by means of PCR-amplified mitochondrial DNA analysis. Fish Bull 94:31-40.

Benzie JAH (2000) Population genetic structure in penaeid prawns. Aquaculture Research 31:95-119.

Bouchon D, Souty-Grosset C and Raimond R (1994) Mitochondrial DNA variation and markers of species identity in two penaeid shrimp species: Penaeus monodon Fabricius and Penaeus japonicus Bate. Aquaculture 127:131-144.

Clary DO and Wolstenholme DR (1985) The mitochondrial DNA molecular of Drosophila yakuba: Nucleotide sequence, gene organization, and genetic code. J Mol Evol 22:252271.

Copert F (1988) Multiple sequence alignment with hierarchical clustering. Nucleic Acids Res 16:10881-10890. http//: prodes.toulouse.inra.fr/multalin.html.

Conn JE (1998) Systematics and population level analysis of Anopheles darlingi. Mem Inst Oswaldo Cruz 93:647-650.

Freitas PD and Galetti Jr PM (2002) PCR-based VNTR core sequence analysis inferring on genetic diversity of cultured prawn Litopenaeus vannamei. Genet Mol Biol 25:431-434.

Gusmão J, Lazoski C and Solé-Cava AM (2000) A new species of Penaeus (Crustacea, Penaeidae) revealed by allozyme and cytochrome oxidase I analyses. Mar Biol 137:435-446.

Iguchi K, Watanabe K and Nishida M (1999) Reduced mitochondrial DNA variation in hatchery populations of ayu (Plecoglossus altivelis) cultured for multiple generations. Aquaculture 178:235-243.

Klinbunga S, Penman DJ, Mcandrew BJ and Tassanakajon A (1999) Mitochondrial DNA diversity in three populations of the giant tiger shrimp Penaeus monodon. Mar Biotechnol 1:113-121.

Kumar S, Tamura K and Nei M (1994) MEGA: Molecular evolutionary genetics analysis software for microcomputers. Comput Appl Biosci 10:189-191.
Lee CE (2000) Global phylogegraphy of a criptic copepod species complex and reprodutive isolation between genetically proximate "population". Evolution 54:2014-2027.

Maggioni R, Rogers AD, Maclean N and D'Incao (2001) Molecular phylogeny of Western Atlantic Farfantepenaeus and Litopenaeus shrimp based on mitochondrial 16S partial sequences. Mol Phylogenet Evol 18:66-73.

Maggioni R, Rogers AD and Maclean N (2003) Population structure of Litopenaeus schmitti (Decapoda, Penaeidae) from the Brazilian coast identified using six polymorphic microsatellite loci. Mol Ecol 12:3213-3217.

Meyer A (1994) DNA technology and phylogeny of fish. In: Beaumont AR (ed) Genetics and Evolution of Aquatic Organisms. Chapman \& Hall, London, pp 220-290.

Nunes AJP (2001) O cultivo de camarões marinhos no nordeste do Brasil. Panorama da Aqüicultura 11:26-33.

Primack RB (2002) Essentials of conservation biology. Sinauer Associates, Massachusetts, $698 \mathrm{pp}$.

Sambrook J, Fritish EF and Maniatis T (1989) Molecular Cloning: A Laboratory Manual. $2^{\text {nd }}$ edition. Cold Spring Harbor Laboratory Press, Cold Spring Harbor.

Sanger F, Nicklen S and Coulson AR (1977) DNA sequencing with chain-terminating inhibitors. Proc Natl Acad Sci 74:5463-5467.

Sekino M, Hara M and Taniguchi N (2002) Loss of microsatellite and mitochondrial DNA variation in hatchery strains of Japanese flounder Paralichthys olivaceus. Aquaculture 213:101-122.

Simon C, Franke A and Martin A (1991) The polymerase chain reaction: DNA extraction and amplification. In: Hewitt GM, Johnson AWB and Young JPW (eds), Molecular Techniques in Taxonomy. Springer-Verlag, Berlin, pp 329-355.

Associate Editor: Sérgio Furtado dos Reis 